\title{
Substance vs. Form in Shareholder Financing: How Does This Affect the Corporate Interest?*
}

\author{
Ferruccio Maria Sbarbaro \\ Link Campus University, Rome, Italy \\ Andrea Sacco Ginevri \\ Cattolica University, Rome, Italy
}

\begin{abstract}
This article analyzes the "substance versus form" contrast in the context of shareholders' financing, exploring how it simultaneously affects both the corporate creditors' protections and the long-term growth of the company. In particular, the paper describes the role of shareholders' financing in the corporation capitalization and its qualification under the current "substance versus form" debate; then it illustrates the substantial approach commonly taken by the case law and explores the effects of the above mentioned debate on the corporate creditors' protections; finally, the paper examines the impact of this practice on the governance side. This article argues that, in a context where substance should govern over form, the most acceptable standards of review should be those that refuse a mechanical application of the formal factors and privilege a comprehensive approach that can lead to a common sense evaluation of the facts and circumstances surrounding a transaction. In other words, the so-called "substantial factors" should certainly be helpful in reaching such a common sense understanding of the transaction since they may show the objective intent of the parties. In short, judicial tools that legitimate and expand the recharacterization of debt to equity are advisable devices because at the same time (1) they strengthen the (actual) corporate creditors' protections; and (2) they foster a long-term growth of the company which benefiting from a conversion of its financial resources into equity (i.e., perpetual capital), may pursue a business strategy more focused on a sustainable and careful development of the enterprise.
\end{abstract}

Keywords: corporate governance, corporate interest, corporate creditors, shareholders’ financing, long-term view, substance vs. form, recharacterization, equity subordination

\section{Introduction}

This article analyzes the "substance versus form" contrast in the context of shareholders' financing, exploring how it simultaneously affects both the corporate creditors' protections and the long-term growth of the company.

In particular, section two-Does substance govern over form in shareholder financing?—-briefly describes the role of shareholders' financing in the corporation capitalization and its qualification under the current

\footnotetext{
${ }^{*}$ This article has been drafted as follows: Sections 2 and 4 by Ferruccio Maria Sbarbaro and Sections 3 and 5 by Andrea Sacco Ginevri. Sections 1 and 6 have been jointly drafted by the Authors.

Ferruccio Maria Sbarbaro, Adjunct Professor of Comparative Law, Link Campus University.

Andrea Sacco Ginevri, Adjunct Professor of Corporate Law, Cattolica University.

Correspondence concerning this article should be addressed to Ferruccio Maria Sbarbaro, via E.Duse n. 37, Rome, 00197, Italy. E-mail: f.sbarbaro@unilink.it.
} 
"substance versus form" debate. Section three-The Substantial Approach in the Case Law illustrates the substantial approach commonly taken by the case law. Section four-How an "equity view" of shareholder financing protects corporate creditors?- explores the effects of the above mentioned debate on the corporate creditors' protections while section five-How an "equity view" of shareholder financing fosters a long-term growth of the company? - examines the impact of this practice on the governance side.

\section{Does Substance Govern Over Form in Shareholder Financing?}

The nature, purpose, and condition of shareholders' loans to a corporation are relevant elements that do affect company's capitalization and the interests of both non-lending shareholders and outside creditors.

In fact, in limited liability firms, there is a substantial risk that shareholders wishing to finance the corporation prefer to contribute through debt instead of equity, on a loan basis, in order to formally acquire a reimbursement priority over other shareholders and keep their contribution safe from capital exposure.

In this context, the impact of a reimbursement obligation on the above interests gets even more sensitive when a corporation approaches the "zone of insolvency" and the contrast between equity holders and creditors degenerates into a dispute, with bankruptcy courts coming into play.

When such issues arise, the analysis of company's capitalization requires an interplay between substance and form, in order to effectively identify whose contributions are located on the "positive side" of an asset distribution, company liquidation or winding-up situation.

Therefore, bankruptcy courts have a general authority to rule that a claim against the trustee, or debtor in possession, should not be considered as an actual debt claim but rather as an equity interest ${ }^{1}$. The result of such a ruling, named "recharacterization", is that the claim is subordinated to all the debt claims of (other) creditors and is treated pari passu (with an equal step) with the claims of the equity holders.

This judicial device differs from another, similar instrument used by bankruptcy courts, namely, the “equitable subordination", which is used to subordinate an actually existing debt claim to those of other creditors, because of some inequitable conduct engaged into by the subordinated creditor, and only to the extent necessary to remedy to the inequitable conduct ${ }^{2}$.

Even though courts themselves have shown a degree of uncertainty in determining whether certain claims had to be recharacterized or equitably subordinated (Nozemack, 1999) ${ }^{3}$, these two mechanisms come into play at different stages and serve different and distinct purposes. The former is used to determine whether a purported debt claim actually exists (or should rather be considered as an equity interest), while the latter establishes a reimbursement hierarchy among different actual creditors and therefore may only be considered when a claim is recognized as being an existing debt claim.

On the other hand, recharacterization does not require any finding of inequitable conduct on behalf of the "lender" and exclusively involves the determination by a court that a transaction which the parties have

\footnotetext{
${ }^{1}$ It is worth noting that a minority of the bankruptcy courts does not recognize the authority to provide such a relief. See e.g., In re Outboard Marine Corp., 50 Collier Bankr. Cas. 2d (MB) 931, 2003 WL 21697357 (N.D. Ill. 2003); In re AutoStyle Plastics, Inc., 269 F.3d 726, 748, 45 U.C.C. Rep. Serv. 2d 964, 2001 FED App. 0378P (6th Cir. 2001). In re Cold Harbor Associates, L.P., 204 B.R. 904, 915, 30 Bankr. Ct. Dec. (CRR) 336, 37 Collier Bankr. Cas. 2d (MB) 753 (Bankr. E.D. Va. 1997), all cited in 2004 Annual Survey of Bankruptcy Law, Sprayregen, Friedland, Brighton, Bianca, Recharacterization of Debt to Equity: An Overview, Update, and Practical Guide to an Evolving Doctrine.

${ }^{2}$ In re AutoStyle Plastics, Inc., 269 F.3d 726, 747, 45 U.C.C. Rep. Serv. 2d 964, 2001 FED App. 0378P (6th Cir. 2001). See also 2004 Annual Survey of Bankruptcy Law, cit.

${ }^{3}$ See also In re AutoStyle Plastics, Inc., 269 F.3d 726, 748, 45 U.C.C. Rep. Serv. 2d 964, 2001 FED App. 0378P (6th Cir. 2001).
} 
characterized as debt should be actually treated as an equity contribution ${ }^{4}$. Of course, if a claim is recharacterized, equitable subordination never comes into play ${ }^{5}$.

Despite the differences between these two devices and their different areas of application, whatever approach to the interpretation of shareholder financing must focus on certain factors, with the purpose of preventing the semblance of the contractual obligation to take over the substance of the financial contribution to the corporation. These factors may be listed as follows: (1) the formalities of the alleged loan agreement; (2) the financial situation of the company and how the parties actually treated the advance; and (3) the relationship between the creditor and the debtor (Nozemack, 1999).

The first group includes those elements that may be referred to as the "formal factors", that can prima facie (on the first appearance) indicating whether the transaction respects the formalities of proper debt transaction, like: (1) the name given by the parties to the instruments, if any, evidencing indebtedness; (2) the presence of a fixed maturity date and schedule of payments; (3) the presence of an interest rate and interest payment; (4) the security, if any, provided by the borrower; (5) the extent to which the claims were subordinated to those of outside creditors; and (6) the presence of a sinking fund to provide repayments.

The second group includes a number of substantial factors, like: (1) adequacy of the capitalization of the company; (2) the sources used for the repayments; (3) the extent to which advances were used to acquire capital assets; and (4) the corporation ability to obtain outside financing.

The third group could be either restricted to a sole substantial factor, namely, (1) the identity of interest between the creditor and stockholder, or extended to include two more elements; (2) the ratio of shareholder loans to capital; and (3) the amount or degree of shareholder control ${ }^{6}$.

With regard to the formal factors it should be doubted why they should be used in determining whether a claim is debt or equity and what function these factors serve. Moving from a presumption that the parties acted in good faith, the formal factors may be seen as a tool used in order to determine the actual intent of the parties with respect to their agreement. One could argue that, if the parties called the relevant instruments with names evidencing a debt transaction, provided for collaterals to secure the repayments and so on, they actually wanted to conclude a debt transaction and, therefore, the court should not consider it as equity.

However, a more pragmatic approach suggests that the formal factors have very little effectiveness, if any, in discovering the actual intent of the parties. To the contrary, if courts relied too much on them, it would become relatively easy for sophisticated parties to obviate the court's scrutiny. This could be done by simply executing a "loan" agreement which provides for: (1) a fixed (but illusory) maturity date; (2) a fixed interest rate (payment for which can be deferred until the maturity date); and (3) the granting of securities for the advance. The unsecured creditors would then be left with the difficult task of uncovering a "smoking gun" that demonstrates that the true intent of the parties was different. The inevitable result would be that recharacterization claims would almost always be rejected, if ever brought to courts.

Therefore, a decisive relevance must be recognized, in this context, to certain substantial factors. For

\footnotetext{
${ }^{4}$ See 2004 Annual Survey of Bankruptcy Law, cit.

${ }^{5}$ LLBL 6.03A, 2010 WL 3878862; In re Georgetown Bldg. Associates, Ltd. Partnership, 240 B.R. 124, 137, 35 Bankr. Ct. Dec. (CRR) 95, 42 Collier Bankr. Cas. 2d (MB) 1946, 42 U.C.C. Rep. Serv. 2d 1050 (Bankr. D. D. C. 1999). See also 2004 Annual Survey of Bankruptcy Law, cit.

6 These factors have been elaborated by the court of In re Outboard Marine Corp., 50 Collier Bankr. Cas. 2d (MB) 931, 2003 WL 21697357 (N.D. Ill. 2003) and derived from In re Hyperion Enterprises, Inc., 158 B.R. 555, 29 Collier Bankr. Cas. 2d (MB) 1281, 24 U.C.C. Rep. Serv. 2d 670 (D.R.I. 1993).
} 
instance, in order to characterize a claim as an equity interest, it is necessary to find an identity of interest between the creditor and the stockholder: It would be unreasonable to think that an external lender, simply because it has provided money to a struggling company, actually intended to realize an equity contribution into such company.

However, the insider status of the lender alone would have little meaning, if it is not put in connection with the overall relationship between lender(s) and borrower. For instance, if shareholders advance money to the corporation in proportion to their respective equity interests, this evidence standing alone is a relevant suggestion that, with the loan, the parties actually intended to conceal an equity contribution ${ }^{7}$. Conversely, if there is a disproportionate ratio between the lender's equity interest in the corporation and the loan, there could be evidence of bona fide (real or done honestly) debt ${ }^{8}$.

Moreover, if the amount of control exercised by the lender on the corporation is increased as a result of the transaction $^{9}$, or more generally, any time a lender obtains the right to control the company's operations (Nozemack, 1999), there should be a reasonable ground to characterize the transaction as equity contribution.

The intent of the parties may also be inferred by the analysis of the way they expect the borrower to use the advances and of the way they expect such advances to be repaid. As to the first issue, a proof of bona fide indebtedness can be identified where the advances are used to meet the daily operating needs of the corporation, rather than to purchase capital assets ${ }^{10}$. However, in these same circumstances, it cannot be excluded that the debtor was in need of working capital and that, therefore, the parties' intent was to provide an equity contribution $^{11}$.

As to the issue of the source of repayment, the general rule is that if the expectation of repayment depends solely on the success of the borrower's business, the transaction has the appearance of a capital contribution ${ }^{12}$. The reason for this rule is clear: If the capital provided is treated by the parties as "risk capital", then the "lender" cannot escape the inherent consequences of business ownership by labeling its investment as "loan".

Thus, as (1) the intent of the parties represents the main —if not the only-element that characterize the transaction as debt or equity; and (2) the purpose of the financing shareholder may be identified only through an investigation of the "substantial factors", the interplay between substance and form should definitely favor the former.

\section{The Substantial Approach in the Case Law}

The major difficulty in determining a clear standard of approach to shareholders' contributions is probably due to the fact that courts employ many different standards of review, without clear indications about what elements - or group of elements—should have prominent relevance. On the contrary, courts say that all the factors taken into account must be weighted as a unique group, so that none of them should be decisive. The characterization of such transactions requires a fact intensive analysis and courts usually prefer to have a

\footnotetext{
${ }^{7}$ In re Cold Harbor, 204 B.R. at 919.

${ }^{8}$ AutoStyle Plastics, Inc., 269 F.3d 726, 751.

9 See Estate of Mixon, 464 F.2d 394, 406 (5th Cir. 1972) (noting that when debtor grants creditor participation in management as result of advances, management participation is evidence of capital contribution by creditor); Cold Harbor, 204 B.R. at 917 (observing that one characteristic of equity contribution is participation in management), both cited in 2004 Annual Survey of Bankruptcy Law, cit., at 711.

10 AutoStyle Plastics, Inc., 269 F.3d 726, 752 (citing Roth Steel Tube, 800 F.2d 625, 632).

11 Matter of Transystems, Inc., 569 F.2d 1364, 1370 (5 $5^{\text {th }}$ Cir. 1978).

12 AutoStyle Plastics, Inc., 269 F.3d 726, 751 (citing Roth Steel Tube, 800 F.2d 625, 631).
} 
case-by-case approach, rather than developing a rigid doctrine to be applied to all cases. Even if such a flexible approach seems appropriate in this context, its inevitable result is uncertainty: Insiders willing to provide cash to a struggling corporation are left without clear indications as to whether their advance will be characterized as equity or debt.

In general, it can be observed that U.S. courts believe in the predominance of substance over form in the context of shareholder financing.

The 3rd U.S. Circuit Court of Appeals, in the opinion of In re Submicron Systems Corporation ${ }^{13}$ citing a dictum of the U.S. Supreme Court in Pepper v. Litton, held that the bankruptcy court's ability to recharacterize purported debt as equity, just like its ability to equitably subordinate debt, is grounded in its equitable authority "to ensure that substance does not give way to form and that technical considerations do not prevent substantial justice from being done"14.

A close examination of how a formal approach can lead to an unfair result can be found in the opinion given in AutoStyle Plastic, precisely in the part where the court analyzes the presence of a fixed interest rate and interest payments ${ }^{15}$. The court says that the agreement provided $a b$ initio (from the beginning) for both an interest rate and interest payment. The parties subsequently agreed to defer interest payments. However, according to the court, this factor is not indicative of equity but, at best, it cuts both ways, since the deferral of interest payment indicates the possibility that during the course of the transaction the defendants eventually never expected to get repaid and converted their debt to equity. Still, it does not change the fact that, initially at least, there was a fixed rate and interest payments, "indicating that the transaction was originally intended to be debt, not equity"16. Thus, according to the court, (1) the original intent of the parties may be inferred by an analysis of the formal factors; and (2) even if the parties eventually acted inconsistently with the intentions stated in the transaction documents, this simply means that they changed their mind during the course of the transaction. However, the court, relying on In re Cold Harbor, stated that such change in the intent of the parties should not be taken into account because "recharacterization applies to transactions that were equity contributions ab initio",17.

Conversely, the court of Submicron System held that the determinative inquiry in classifying advances as debt or equity is the intent of the parties "as it existed at the time of the transaction"18. In this case, the court (which included now Supreme Court Justice Alito) refused to apply a multi-factor tests and, rather, focused more generally on the intent of the parties. The court stated that the multi-factor tests undoubtedly include pertinent factors, but they devolve to an overreaching inquiry: The characterization as debt or equity is a court's attempt to discern whether the parties "called an instrument one thing when in fact they intended it as something else". Then the court goes on saying that the intent of the parties may be inferred, among other things, also "from what they say in their contracts" ${ }^{, 19}$. However, thereafter the court adds that "form is no doubt a factor, but in the end it is no more than an indicator of what the parties actually intended and acted on". In the same opinion, the court also recognizes that no mechanistic scorecard suffices and that answers lie in facts that

13432 F.3d 448, 455-56 (3d Cir. 2006).

14308 U.S. 295, 305, 60 S.Ct. 238, 84 L.Ed. 281 (1939), emphasis added.

15 AutoStyle Plastics, Inc., 269 F.3d 726, 751.

${ }_{16}$ AutoStyle Plastics, Inc., 269 F.3d 726, 751, emphasis added.

17 AutoStyle Plastics, Inc., 269 F.3d 726, 751, emphasis added.

18432 F.3d 448, 457 (3rd Cir. 2006).

19 In re Submicron System Corporation, 432 F.3d 448, 456 (3rd Cir. 2006). 
confer context case-by-case. It is worth to underline that the other two elements mentioned by the court as indicators of the parties' intent are: (1) what the parties do through their actions; and (2) the economic reality of the surrounding circumstances, which indeed appear to be more powerful tools than a mere review of the formalities set up by the parties.

Consistently, the court of In re Phase-I Molecular Toxicology was persuaded that the transaction was a loan and not an equity contribution, inter alia (among other things), by the fact that the intended repayment was expected to be received from the sale of assets and, therefore, was not entirely dependent on the future success of the debtor's business ${ }^{20}$.

As discussed above, the two groups of substantial factors elaborated in AutoStyle Plastic and in Outboard Marine include the following elements: (1) the financial situation of the company and how the parties actually treated the advance, including: the adequacy or inadequacy of capitalization; the sources used for the repayments; the extent to which advances were used to acquire capital assets; and the corporation ability to obtain outside financing; and (2) the relationship between the creditor and the debtor, including: identity of interest between the creditor and stockholder; the ratio of shareholder loans to capital; and the amount or degree of shareholder control.

In AutoStyle Plastic the court applied an 11-factor test derived from a tax case, Roth Steel Tube, in which the issue was recharacterization of tax claims ${ }^{21}$.

Such substantial factors can be used by courts for determining the real intent of the parties in connection with a given transaction and are the most commonly accepted elements used by courts to evaluate whether a debt claim should be recharacterized to equity.

Some courts, following the approach indicated by Submicron System, are starting to refuse the application of a multi-factor test, while privileging a case-by-case approach that can lead to a common sense evaluation of the facts and circumstances surrounding a transaction ${ }^{22}$. However, as can be seen from above, such common sense approach will not differ too much, and probably cannot prescind from, an analysis of at least some of the substantial factors, in particular (1) what the parties do through their actions; and (2) the economic reality of the surrounding circumstances ${ }^{23}$.

An increased focus on the substantial elements of the transaction is clearly shown by the Courts of Appeal for the Eleventh and Fifth Circuits in some tax cases ${ }^{24}$. In these cases, the courts employed a 13-factor test, very similar to the so called "AutoStyle Plastic test", with the significant difference that they mentioned the "intent of the parties" as a distinct and additional factor with respect to the formal ones. In particular, in Estate of Mixton, the court draws a distinction between the subjective and objective intent of the parties ${ }^{25}$. According to the court, the parties' intent to create either a debt or equity relationship is the ultimate issue to be determined. However, the court goes on, notwithstanding their subjective belief, the parties may objectively manifest their intent through their actions, also taking into account the economic reality in which they acted. Therefore, the crucial point of this issue is understanding whether the subjective intent of the parties, as expressed in the

${ }^{20}$ In re Phase-I Molecular Toxicology, 287 B.R. 571, 577, 49 Collier Bankr. Cas. 2d (MB) 1375 (Bankr. D. N.M. 2002).

${ }^{21}$ Roth Steel Tube Co. v. C.I.R., 800 F.2d 625, 86-2 U.S. Tax Cas. (CCH) ๆ 9676, 58 A.F.T.R.2d 86-5808 (6th Cir. 1986).

22 Radnor, 353 B.R. 820, 838; 2006 Bankr. LEXIS 3699, 36.

23432 F.3d 448, 457 (3rd Cir. 2006).

24 Stinnett's Pontiac Serv., Inc. v. Comm'r, 730 F.2d 634, 638 (11th Cir.1984) (citing Estate of Mixon v. United States, 464 F.2d 394, 402 (5th Cir.1972)) both cited in Submicron System.

${ }^{25}$ Estate of Mixon v. United States, cit., 407. 
corporate documentation, should be disregarded in characterizing the transaction. The answer of the court to this question is that there is a well-recognized principle in all areas of the law: That a subjective intent on the part of an actor will not alter the relationship or duties created by an otherwise objectively indicated intent. This approach clearly recalls a substantial way of thinking of shareholder financing characterization, indicating that the substantial factors should have prominent importance in order to infer the (objective) intent of the parties ${ }^{26}$. In other words, the actual behavior of the parties, in connection with the economic reality in which they acted, can say more about their intent than the facial appearance of the transaction. This is what the court implies when, citing Tyler $v$. Tomlinson ${ }^{27}$, it says that law requires that creditorship has genuine existentiality and that "This requires more than a declaration of intention to create an indebtedness and more than the existence of corporate paper encrusted with the appropriate nomenclature captions, ${ }^{28}$.

In the same line of reasoning, in Stinnett's Pontiac the court, recalling somehow the wording of the Supreme Court in Pepper v. Litton, says that to hold that the subjective intent of the parties should prevail over their objective intent would be to ignore the plain facts and to elevate form over substance ${ }^{29}$.

Thus, if - as suggested above - the formal factors should not be considered in order to determine the intent of the parties, what is their proper role in the context of shareholder financing characterization? Should courts continue to take into account these elements?

A possible answer to these questions might be that, due to the scarce effectiveness these factors have in understanding the real nature of a transaction, courts should give them a more limited consideration.

In particular, the suggestion is that these factors should be treated as "negative" factors, meaning that their presence should be generally seen as a (very weak) indication of a debt transaction, but only if the analysis of the substantive aspects of the transaction points to the same conclusion; conversely, their absence should be seen - of course always in the light of the other factors - as a strong indication of an equity contribution, especially (or maybe even exclusively) in the context of a transaction between sophisticated parties, which would very unlikely enter into a real debt transaction without the proper transaction documentation and adequate guarantees in place.

This seems particularly evident, for example, thinking about elements such as: (1) the name given by the parties to the instruments, if any, evidencing indebtedness; (2) the presence of a fixed maturity date and schedule of payments; (3) the presence of an interest rate and interest payment; (4) the security provided by the borrower; or (5) the presence/absence of a sinking fund.

\section{How an "Equity View" of Shareholder Financing Protects Corporate Creditors?}

The consequences of a predominance of substance over form in case law may touch the positions of different classes of stakeholders and therefore, considering the combination and the bi-lateral effects of inside and outside corporate governance elements and controls, affect the balance of the heterogeneous interests wheeling around the corporation.

In fact, from a corporate governance point of view it may be possible to determine whether a potential

\footnotetext{
${ }^{26}$ This issue will be discussed in further detail below. This essay suggests that some of the substantial elements should also be taken into account in determining the level of dangerousness of the transaction with respect to the rights of outside bona fide creditors.

27 Tyler v. Tomlinson, 414 F.2d at 850.

28 Estate of Mixon v. United States, cit., 407.

29 Stinnett's Pontiac, cit., at 639 (citing Tyler v. Tomlinson, cit., at 850).
} 
effect of such a ruling on a company's "inside” corporate governance (shareholders-directors relationships and controls) could generate a benefit also for outside creditors and other stakeholders. A starting point could be set as follows:

The equity capital of a company may be regarded as a minimal and basic protection granted (among others) to: (1) trade creditors (in general, unsophisticated third parties that decide to deal with a company but cannot or do not want to provide independently for more intensive tools (Lutter, 2006)); and/or (2) involuntary creditors of the company (e.g., holders of a credit deriving from a damage claim).

Many legal systems, especially those of European civil law countries, set forth specific rules on the constitution of the corporate capital and its minimum amount, which vary depending on the kind of corporate entity and on the industry in which the latter is involved (i.e., the minimum amount of capitalization increases according to the presumed magnitude of the activities carried out and the inherent amount of risk with respect to third parties). The adoption of rules on minimum capitalization is perhaps more justified in civil law systems, where judges prefer to enforce relatively bright-line rules, rather than develop standards for the protection of corporate creditors, such as fiduciary duties, piercing the veil, fraudulent conveyance, equitable subordination, recharacterization, and other instruments developed in common law jurisdictions (Lutter, 2006, p. 653).

The balance points between the advantage of limited liability and a fair use of the corporate entity vary from one to the other legal system, but all western legal systems share the same ultimate goal: preventing shareholders from avoiding the responsibilities and risks related to entrepreneurial activities by unfairly manipulating the corporate instruments to their advantage (Dooley, 1992; Enriques, 2003; Hopt, Kanda, Roe, Wymeersch, \& Prigge, 1998; Visentini, 1998; Cheffins, 1992; Hopt, 2010; 2011).

Bankruptcy courts constantly see the undercapitalization of the borrowing company as an index of a suspicious transaction, whereas, from a doctrinal point of view, undercapitalization may be divided into two categories: "nominal” and “material” undercapitalization. A corporation is "nominally undercapitalized", even though it actually has sufficient financial means to pursue its corporate purpose and to face its obligations towards outside creditors, such financial means are mainly provided by the shareholders as debt capital, rather than as "risk capital" (i.e., equity, which is instead provided to an insufficient extent). Conversely, a corporation is "materially undercapitalized" when both equity and "debt" contributions are insufficient, with the result that the corporation is unable to face its obligations as they become due (Portale, 1991).

As specified above, the event that triggers the possibility to bring a claim for recharacterization of debt to equity is the initiation of a bankruptcy proceeding, meaning that the corporation, at a certain moment in its life, became "materially undercapitalized". However, when bankruptcy courts analyze the capitalization of a corporation in order to understand whether it is adequate or inadequate to prevent it to fall in the "zone of insolvency", they implicitly refer to the concept of "nominal undercapitalization" (Sbarbaro, 2012), which is generally seen as a strong evidence of an equity contribution.

For example, the court of In re Cold Harbor stated that the issue of undercapitalization is particularly important when the corporation is started by the shareholders with a minimal amount of capital, who then make a large loan of money to the newly formed corporation ${ }^{30}$. Also, in Pepper v. Litton, the U.S. Supreme Court stated that so-called loans or advances by a dominant or controlling shareholder will be subordinated to claims of other creditors, and thus treated as capital contributions, where the paid-in capital is purely nominal, the

${ }^{30}$ In re Cold Harbor, 204 B.R. at 917. 
capital necessary for the scope and magnitude of the operations of the company being furnished by the stockholders as a $\operatorname{loan}^{31}$.

According to the Supreme Court, shareholders should not be allowed to manipulate the corporate device in order to avail themselves of privileges normally permitted to outside creditors, so that a transaction shall be characterized as equity if there was an ongoing situation of nominal undercapitalization before the relevant transaction was carried out, without the burden to prove that the borrower was materially undercapitalized.

Slightly differently, the court of Diasonics, Inc. v. Ingall stated that capitalization is inadequate, in the opinion of a skilled financial analyst, it would definitely be insufficient to support a business of the size and nature of the bankrupt in light of the circumstances existing at the time the bankrupt was capitalized ${ }^{32}$. Such a definition of inadequate capitalization recalls the same policy reasons underlying the rules on minimum corporate capital of civil law systems: The higher is the risk for third parties in connection with the activities carried out by the corporation, the higher must be the capitalization.

The efforts to protect outside creditors have been brought to extreme consequences by some courts, in particular, the court of Diasonics ${ }^{33}$ — which held that shareholder loans shall be characterized as equity contribution in one of two circumstances: (1) where the plaintiff proves initial undercapitalization; or (2) where the plaintiff proves that the loans were made when no other disinterested lender would have extended credit ${ }^{34}$. These two circumstances are not cumulative and therefore it is sufficient that only one of them is proven by the plaintiff, at least in the 11th Circuit ${ }^{35}$; furthermore, from a literal reading of the opinion, it seems sufficient that a corporation was initially undercapitalized in order to characterize as capital contribution any shareholder financing. However, this approach reveals several criticalities, as underlined by the following example.

A corporation is started with insufficient capital but, during the course of its life, is adequately capitalized with equity contributions by stockholders. After several years, during which the corporation entered in dealing with third parties and regularly met its obligations, the corporation begins to suffer overwhelming losses due to deteriorated market conditions. In such a situation, an insider would probably be the only entity willing to extend credit to the corporation. In this case, the application of a strict Diasonics test would certainly lead to the recharacterization of any shareholder loan to an equity contribution. In particular, a per se (in itself) application of the second factor mentioned above would prevent any shareholder or insider from ever loaning money to a company experiencing distress ${ }^{36}$.

As seen from above, a formal interpretation of the test developed by the 11th Circuits could lead to undesirable results, proving once again that substance shall govern over form in order to prevent shareholders from manipulating the corporate devices avoiding the consequences of business ownership.

31 Pepper v. Litton, cit. at 309-310.

32 Diasonics, Inc. v. Ingall, 121 B.R. 626, at 631 (citing In re Multiponics, 622 F.2d 709, 717 (5th Cir. 1980)).

33 Diasonics, Inc. v. Ingall, 121 B.R. 626, at 631.

34 In re N\&D Properties, Inc., 799 F.2d 726 (11th Cir. 1986).

35 See also In re N \& D Properties, Inc., 799 F.2d 726, 733, 15 Bankr. Ct. Dec. (CRR) 254, 15 Collier Bankr. Cas. $2 d$ (MB) 726 (11th Cir. 1986) (Shareholder loans may be deemed capital contributions in one of two circumstances: where the trustee proves initial undercapitalization or where the trustee proves that the loans were made when no other disinterested lender would have extended credit); Matter of Herby’s Foods, Inc., 2 F.3d 128, 132, 24 Bankr. Ct. Dec. (CRR) 1116, 29 Collier Bankr. Cas. 2d (MB) 1375, Bankr. L. Rep. (CCH) I 75446 (5th Cir. 1993) (If an insider makes a loan to an undercapitalized corporation, the combination of undercapitalization and the insider loan may allow the bankruptcy court to recharacterize the loan as a capital contribution); Matter of Fabricators, Inc., 926 F.2d 1458, 1469, 21 Bankr. Ct. Dec. (CRR) 809, 24 Collier Bankr. Cas. 2d (MB) 1489, Bankr. L. Rep. (CCH) 73875 (5th Cir. 1991) (When an insider makes a loan to an undercapitalized corporation, a court may recast the loans as contributions to capital).

362004 Annual Survey of Bankruptcy Law, cit. 
Therefore, those bankruptcy courts which rely on substantive factors in order to determine the actual intent of the parties better protect the interests of both non-financing shareholders and outside creditors, suggesting that this standard of review would be the most suitable.

Moreover, the role of the substantial factors should not be limited to this, because the courts have often relied on these factors also in order to determine the degree of dangerousness of a transaction with respect to the outside bona fide creditors of the company, showing an even more "defensive" effect of the substantial approach to shareholder financing, which could work as an ex ante (before the event) protection for every stakeholder.

\section{How an "Equity View" of Shareholder Financing Fosters a Long-Term Growth of the Company?}

From a "global" corporate governance perspective, legal devices that help to increase the capital adequacy of the corporations, as long as they are not driven by a formal approach, seem to stimulate better corporate governance by helping management and directors to act with a long-term focus. This also means-as introduced above - that a "two-tier benefit" could reach the outside creditors of the corporation: On the one hand, a device such as recharacterization directly protects the corporation's capitalization; on the other hand, long-term corporate strategies, focusing on the corporation's stability and development process (Gilson, 1996; Easterbrook \& Fischel, 1991), provide an indirect protection for outside creditors and for the qualified interests of the stakeholders in general (Freeman, 2010; Freeman \& Evan, 1988).

Of course, it is difficult to find the right balance between the legitimate reasons of creditors and the equally legitimate interest of shareholders of keeping the corporation alive and protecting their initial equity interest. As said, the Diasonics test is probably overreaching, given that its second prong actually prohibits any insider loan to undercapitalized entities. On the other hand, it seems reasonable to hold that if a company was undercapitalized both at the beginning of its life and at the time of the transaction, shareholders should not be allowed to have their claim repaid before, or pari passu (with an equal step) with, outside creditors. As a matter of fact the majority of courts, consistently with the above considerations, does not believe that undercapitalization must be present only at the beginning of the life of the corporation. This is evident, for example, in AutoStyle Plastic, where the court pointed out that capitalization is not to be assessed only at the moment of initial capitalization, but also at the time when the advance was made.

Therefore, enduring undercapitalization is one of the most important elements to be considered by courts, even though this element is not per se sufficient to characterize a purported debt claim as equity. Interestingly, the Fourth Circuit noted that a claimant's insider status and a debtor's undercapitalization alone will normally be insufficient to support the recharacterization of a claim, suggesting that in many cases, an insider will be the only party willing to make a loan to a struggling business, and recharacterization should not be used to discourage good-faith loans ${ }^{37}$.

In AtlanticRancher, the court tried to put in relation the financial failure of the debtor with its "chronic undercapitalization", focusing on whether or not undercapitalization was the most important cause of the debtor's financial failure ${ }^{38}$.

\footnotetext{
37 28-2 ABIJ 42, 42-43, citing In re Official Committee of Unsecured Creditors for Dormer Aviation (N. Am.) Inc., 453 F.3d 225, 234 (4th Cir. 2006).

${ }^{38}$ In re AtlanticRancher, Inc., 279 B.R. 411, 436 (Bankr. D. Mass. 2002).
} 
According to this approach, one could argue that, if the company is deliberately kept by shareholders in a chronic condition of undercapitalization (even only nominal), when such shareholders decide-in order to remedy to a contingent situation of material undercapitalization - to extend a loan to the company, they should not be allowed to the protections of genuine creditorship if the corporation then actually goes bankrupt. Again, form would prevail over substance and compress the corporate interest.

An additional element that courts often take into consideration is whether the loan had the character of an arm's length transaction and, in particular, whether bankruptcy was actually evitable when the loan has been extended to the debtor. In particular, the court of Trimble held that at the time of the loan no financial institution would have been willing to extend credit, because the business was a "hopelessly insolvent corporate structure,39.

One of the policy reasons why insider loans should not be discouraged is that they may be the only means to keep a distressed corporation alive, but it is also true that, if the overall circumstances suggest ex ante that the corporation will soon become insolvent, the insider should not be encouraged to extend a useless loan to such a corporation. Timing also matters in such a situation: One of the elements that could be considered in order to determine whether the insider-lender was aware (or ought to be aware) of the inevitability of bankruptcy could be the closeness of the transaction to the actual beginning of the bankruptcy proceeding. Even if it would be risky to give too much relevance to such a temporal factor (substance should win over form also in this context), it seems certainly reasonable to think that a shareholder loan extended on the verge of bankruptcy should be subject to careful judicial scrutiny.

Here come again the basic policy questions underlying the "equity view": Should shareholder loans to distressed companies be permitted or prohibited? Do transactions of this kind impair the rights of outside bona fide creditors $^{40}$ ? Does the characterization of shareholder financing influence the corporate governance of the company?

The basic answer that should be given to these questions is that shareholder loans to a company facing liquidity crisis should not be per se prohibited. As discussed above, if a shareholder loan is the only way to keep the corporation alive and avoid bankruptcy, it seems excessive to think that shareholders should not be permitted to finance corporation.

If the corporation is facing material undercapitalization, a cash contribution by an insider can be beneficial also to pre-existing outside unsecured creditors. In fact, cash streams going into the company, would normally be used to meet the debtor's obligations toward outside creditors as they become due and, therefore, would be somehow "distributed" to them. Such an argument could be used to justify the permissibility of shareholder loans in the above mentioned situation as happened in AutoStyle Plastic, where it has been stated that the use of advances to meet the daily operating needs of the corporation, rather than to purchase capital assets, is indicative of bona fide indebtedness ${ }^{41}$.

In the light of above, this ruling assumes a new significance: Besides the aim of determining the parties' intent, such factor may also be used in order to evaluate whether the transaction is beneficial or detrimental to

\footnotetext{
39 In re Trimble Co., 479 F.2d 103, 118 (3d Cir. 1973).

${ }^{40}$ Furthermore, assuming that in certain circumstances shareholders are the only subjects willing to provide cash to a struggling corporation, how should the legitimate purpose of keeping the corporation alive be balanced with the rights of outside bona fide creditors?

41 AutoStyle Plastics, Inc., 269 F.3d 726, 752 (citing Roth Steel Tube, 800 F.2d 625, 632).
} 
pre-existing outside creditors. In any case, without such transaction, the company would remain "materially undercapitalized", and therefore, outside unsecured creditors would normally not be able to recover the whole amount of their respective credits from a bankruptcy proceeding.

Although this argument seems acceptable from the pre-existing creditors' point of view, it could be pointed out that, after the shareholder loan is extended to the company, it will not be materially undercapitalized anymore, but would then become nominally undercapitalized. Such corporation will then continue to deal with pre-existing creditors accumulating new indebtedness (e.g., trade creditors will probably continue to provide goods or services to the corporation) and probably will also enter into some kind of relationship with new voluntary creditors (e.g., new suppliers) or even with involuntary creditors (e.g., someone who is damaged by the corporation). In this case, the post-transaction creditors will be dealing with a nominally undercapitalized company and, in case of insolvency of the latter, they will concur pari passu with the insider-lender for the satisfaction of their credit. It would be also realistic to assume that insider-lenders would usually secure their credit with a lien over (some of) the assets of the corporation, so that the post-transaction outside creditors will also be deprived of the value of such assets as a source for the repayment of their credit.

These risks for outside creditors are not merely theoretical and it must be borne in mind that, if a recharacterization claim has been brought before a court, it means that the debtor eventually became insolvent and that there is an actual ongoing bankruptcy proceeding. In these circumstances, it is hard to argument that the shareholder loan was beneficial to post-transaction outside unsecured creditors, especially those who became creditors of the corporation in a period of time close to the beginning of the bankruptcy proceeding.

In a time where corporate governance systems around the world are converging towards the long-term growth of the companies, the above mentioned conclusions generally have a consistent impact on corporate governance.

If corporate managers' obsession with short-term shareholder wealth maximization has, in many instances, diverted their attention from the efficient operation of their companies, in order to make the company profitable in the long run, corporations need to invest capital in the long-term endeavours, which often have a significant time lag between the time of investment and the eventual returns (Sacco Ginevri, 2011) .

Therefore, assuming that companies should be managed with a long-term view, whenever equity prevails over debt (and substance over form), corporate managers could pursue the creation and preservation of the sustainable economic long-term growth of their company, because the interest represented by the stock is generally of unlimited duration ${ }^{42}$ - so allowing directors to invest in long-term strategies-while short loan duration is generally preferred by lenders to limit the danger to debtholders of wealth transfers to equity-holders resulting from investment and dividend decisions (Klein, Coffee, \& Partonoy, 2010).

A third "contrast" could then be observed in the context of shareholder financing characterization: After "debt vs. equity” and "substance vs. form”, "short term vs. long term” should also acquire importance as a legitimacy standard for both shareholder loans and corporate governance strategies.

\section{Conclusions}

In a context where substance should govern over form, the most acceptable standards of review should be those that refuse a mechanical application of the multi-factor tests and privilege a comprehensive approach that

\footnotetext{
42 In other words, there is usually no initially agreed-upon point in time when a common shareholder becomes entitled to demand the return of his or her initial contribution or some other amount.
} 
can lead to a common sense evaluation of the facts and circumstances surrounding a transaction ${ }^{43}$.

In other words, the so-called "substantial factors" should certainly be helpful in reaching such a common sense understanding of the transaction since they may show the objective intent of the parties.

In short, judicial tools that legitimate and expand the recharacterization of debt to equity are advisable devices because at the same time (1) they strengthen the (actual) corporate creditors' protections; and (2) they foster a long-term growth of the company which—benefiting from a conversion of its financial resources into equity (i.e., perpetual capital) — may pursue a business strategy more focused on a sustainable and careful development of the enterprise.

\section{References}

Cheffins, B. (1992). The history of corporate governance. ECGI Law Working Paper No. 184/2012.

Dooley, M. P. (1992). Two models of corporate governance. Business Lawyer, 47, 461-465.

Easterbrook, F. H., \& Fischel, D. R. (1991). The economic structure of corporate law. Cambridge, M.A.: Harvard University Press.

Enriques, L. (2003). Corporate governance codes, corporate law and proprietorships: Some preliminary thoughts (Codici di corporate governance, diritto societario e assetti proprietari: alcuni aspetti preliminari). Banca Impr. Soc., 1, 97.

Freeman, R. E. (2010). Strategic management: A stakeholder approach. Cambridge, UK: Cambridge University Press.

Freeman, R. E., \& Evan, W. (1988). A stakeholder theory of modern corporation: The Kantian capitalism. Englewood Cliffs, N.J.: Prentice Hall.

Gilson, R. J. (1996). Corporate governance and economic efficiency: When do institutions matter. Washington University Law Quarterly, 74(2), 327-345.

Hopt, K. (2010). Comparative corporate governance: The state of the art and international regulation. ECGI Law Working Paper No. 170/2011.

Hopt, K. (2011). Corporate governance of banks after the financial crisis. ECGI Law Working Paper No. 181/2011.

Hopt, K. J., Kanda, H., Roe, M. J., Wymeersch, E., \& Prigge, S. (1998). Comparative corporate governance-The state of art and emerging research. New York: Oxford University Press.

Klein, W. A., Coffee, J. C., \& Partonoy, Jr. F. (2010). Business organization and finance (p. 282). New York: Foundation Press.

Lutter, M. (2006). Das Kapital der Aktiengesellschaft in Europa. Berlin: De Gruyter.

Nozemack, M. (1999). Making sense out of bankruptcy courts' recharacterization of claims: Why not use $\$ 510(c)$ equitable subordination?. Retrieved from http://scholarlycommons.law.wlu.edu/wlulr/vol56/iss2/8

Portale, G. B. (1991). Share capital and undercapitalized joint stock company (Capitale sociale e società per azioni sottocapitalizzata). Rivista delle società, 1, 29-30.

Sacco Ginevri, A. (2011). The rise of long-term minority shareholders' rights in publicly held corporations and its effect on corporate governance. European Business Organization Law Review: EBOR, 12(4), 587-619.

Sbarbaro, F. M. (2012). The solvency test in the U.S. legal system (Il solvency test nell'ordinamento statunitense). Comparative Civil Law, 11, 1-20.

Visentini, G. (1998). Compatibility and competition between European and American corporate governance: Which model of capitalism?. BROOK. J. INT'L L., 3, 836-837.

${ }^{43}$ Radnor, 353 B.R. 820, 838; 2006 Bankr. LEXIS 3699, 36. 